\title{
USING GEODESIC DOMES OF WOOD AND THERMOPLASTICS FOR ROTATIONAL CAMPS IN THE ARCTIC AND NORTHERN TERRITORIES
}

\author{
Dmitriy Zhivotov*, Valeriy Latuta
}

Saint Petersburg State University of Architecture and Civil Engineering

Vtoraja Krasnoarmeyskaya st., 4, Saint Petersburg, Russia

*Corresponding author: d.zhivotov@mail.ru

\begin{abstract}
Introduction: The use of modern construction materials and technologies makes it possible to take a different view of such long-span spatial structures as geodesic domes that seem quite familiar for architects and engineers. Methods: Based on studies of Russian and foreign researchers, the authors of the article suggest using the space between two geodesic domes for residential, administrative as well as laboratory and research facilities. Results: It is suggested to use this type of structures of wood and thermoplastics for rotational camps in the Arctic and Northern territories. Discussion: The authors conduct experimental studies to justify that it is possible to manufacture joint connections of various types of plastic.
\end{abstract}

\begin{abstract}
Keywords
Housing construction, architecture, civil engineering, frozen sample testing.
\end{abstract}

\section{Introduction}

The practice of using geodesic domes dates back to the founder of the "geodesic dome" project, Buckminster Fuller. R. B. Fuller had developed a spatial structure of a dome in the form of a hemisphere made of tetrahedrons since 1947. He applied for a patent in 1951. Geodesic domes brought international recognition to R. B. Fuller (a "golden dome" was built for the American National Exhibition in Moscow in 1959, and in 1967 - the US pavilion at the International and Universal Exposition in Montreal) (Livelnternet, 2020).

The practical use of the building outline geometry proposed by R. B. Fuller is based on the division of space by vectors. The main unit of this division is a tetrahedron. Its faces are located at the shortest distance that connects two points on a curved surface (geodesic lines). The above division allows us to achieve optimal space-filling and the most complete utilization of the structural strength of materials.

The main advantages of geodesic domes are as follows:

- high load-bearing capacity (the more the dome is, the higher it is);

- fast assembly as compared to traditional frame and frameless methods of construction;

- the weight of the dome elements reduces the cost of materials and preparatory works;

- one of the structural and technological features of spatial dome structures is the installation of frame elements from marked rods and nodes, which reduces the construction time. The cellular structure will allow the assembly of blocks of cells, which will significantly reduce the construction time of the building (Wu and Takatsuka, 2006);
- dome structures have an ideal aerodynamic shape with high resistance to seismic, wind and hurricane impacts. Scientists continue to study the possibility of using geodesic domes by changing their shape, configuration, manufacturing material and many other parameters (Guan et al., 2018);

- cellular configuration of many available Diamatic dome templates is particularly convenient for conversion with mutual element support. This is due to the fact that at any vertex only three elements of the lattice rods intersect, regardless of the number of rod elements used to form the polygon of the node (Rizzuto, 2018);

- Coating with the use of natural renewable energy sources. The use of the surface of geodesic domes is a great option in this case (Porta-Gándara and GómezMuñoz, 2005).

The disadvantages of geodesic domes include the fact that the production of modern building materials is aimed primarily at the construction of buildings made of rectangular materials (plywood, glass, rigid blankets).

Thus, triangular cells of geodesic domes will require additional labor to trim and fit the material to create external enclosing structures with a large overspend, increasing the cost and complexity of manufacturing the building as a whole. It should be noted that all existing patented solutions use metal for nodes and connections (in the form of bolts, pins with washers and nuts), which extremely negatively affects the condition of the dome structure in general in harsh chemical environments. As a rule, these are warehouses for salines, chemical fertilizers, reagents, etc. (Zhivotov and Latuta, 2019).

One of the great Fuller's projects was Cloud Nine. According to his idea, airborne habitats could be created from giant geodesic spheres, which might be made to 
levitate by slightly heating the air inside (Fig. 1). Geodesic spheres (structures of triangular components arranged to make a sphere) become stronger as they become bigger, due to how they distribute stress over their surfaces. In theory, such structures can be gigantic. As a sphere gets bigger, the volume it encloses grows much faster than the mass of the enclosing structure itself. Fuller suggested that the mass of a mile-wide geodesic sphere would be negligible compared to the mass of the air trapped within it. He suggested that if the air inside such a sphere was heated even by one degree higher than the ambient temperature of its surroundings, the sphere could become airborne. He calculated that such a balloon could lift a considerable mass, and hence that 'mini-cities' or airborne towns of thousands of people could be built in this way (Ongreenway, 2020).

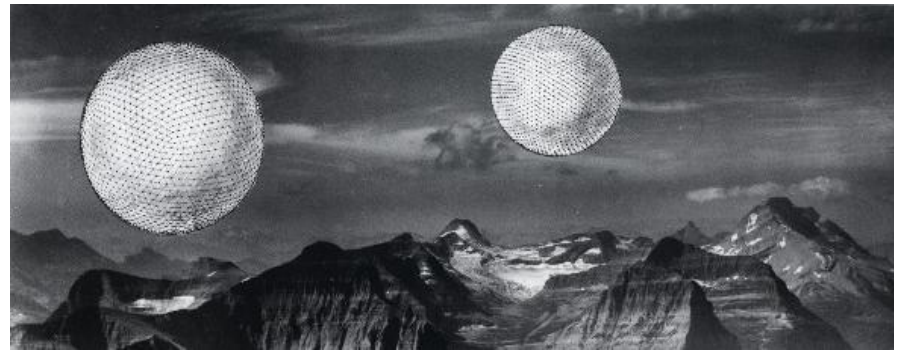

Fig. 1. Houses according to the Fuller's idea (created by R. B. Fuller)

Such buildings primarily serve as industrial enterprises and factories, warehouses, public and exhibition halls.

In November 2019, an experimental dome was erected over a residential house in Yakutsk, Yakutia (Tomsky, 2019). It has various sensors for measuring the humidity and temperature, including in the area of the house foundation located in permafrost conditions (the first experimental dome in Yakutsk).

Sweden also has similar experience in creating a second-level space above residential houses (Forumhouse, 2020).

Fig. 2 demonstrates the idea of covering blocks with a dome.

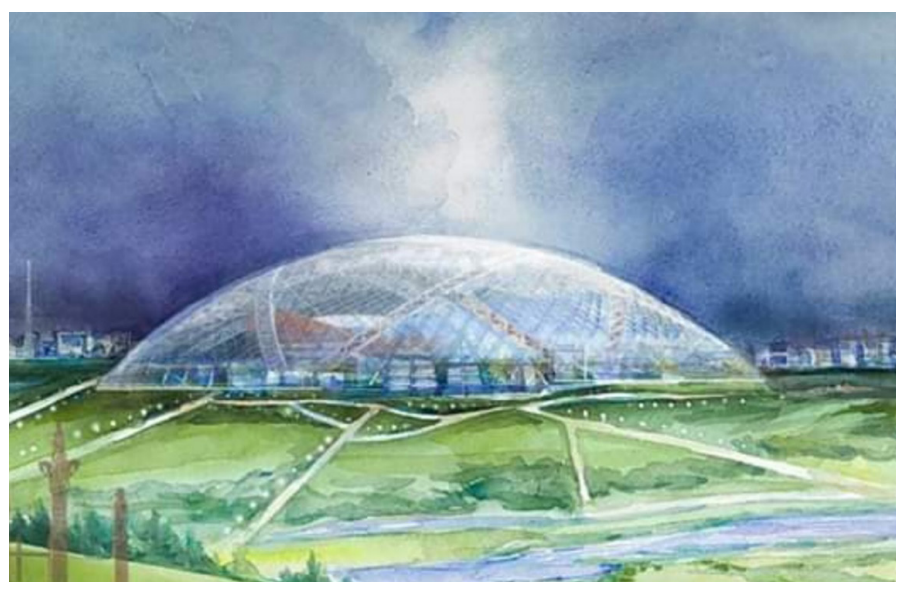

Fig. 2. A settlement under a dome (Ignatyeva, 2019)

\section{Methods}

\section{Architectural solutions for dome spaces}

The authors propose considering the functions of the above examples more widely, using geodesic domes to cover rotational camps in the Arctic and other Northern regions (Fig. 3). The climate in these regions significantly complicates the conditions of life and work. The creation of a special microclimate in the inner space will have a positive impact on the emotional and physical condition of people. Modern engineering systems and equipment ensure the self-sustainability of life under such a dome.

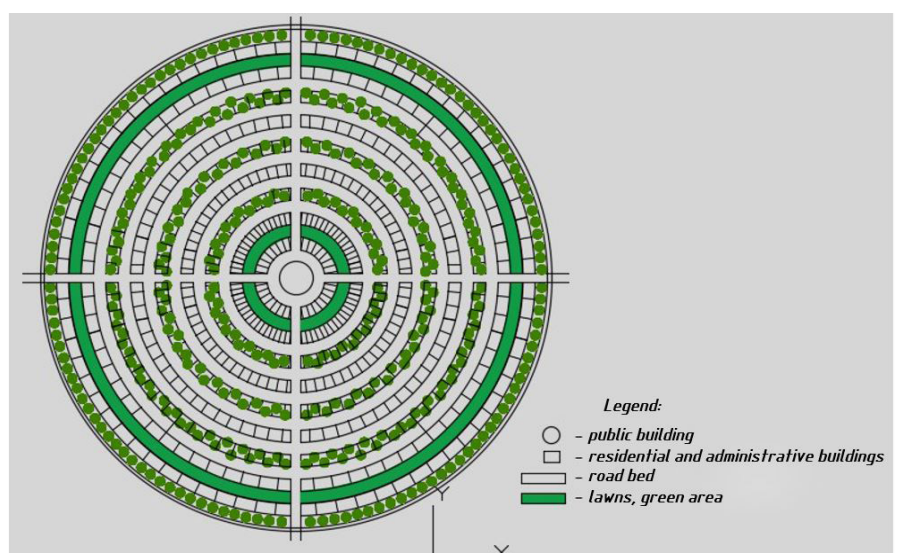

Fig. 3. A geodesic dome above a rotational camp (possible architectural solutions)

Based on studies of Russian and foreign researchers, the authors of the article suggest using the space between two geodesic domes for residential, administrative as well as laboratory and research facilities (Fig. 4).

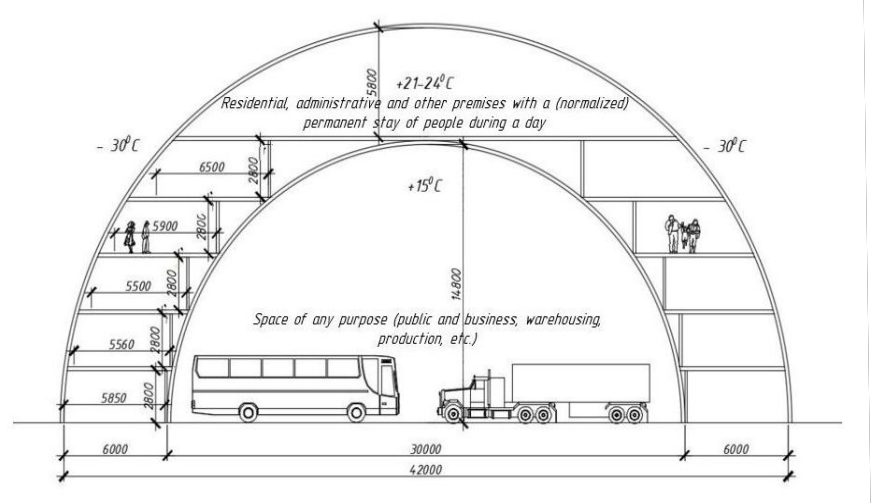

Fig. 4. Space between two domes

It should be noted that all existing patented solutions use metal for nodes and connections (in the form of bolts, pins with washers and nuts), which extremely negatively affects the condition of the dome structure in general in harsh chemical environments and at low temperatures below zero.

However, there are also solutions made of wood and polymeric materials (Bushin et al., 2017). Based on the above solutions, the authors continue to study joint connections of wood and polymers with various temperature conditions.

In the construction market, there are small prefabricated houses available (Icedom, 2020).

Domes of various sizes can be provided for outdoor events. The structure is characterized by extreme wind resistance. It can withstand static loads such as alternating 
lighting and sound, and provides many opportunities for specific equipment options (DOMZELT Deutschland, 2020).

The construction market also suggests combining geodesic domes with earth-sheltered buildings (Geodesic Earthworks, 2020).

\section{STUDYING THE FORMATION OF THE ARCHITECTURAL FORM IN COMPARISON TO THE NATURAL MORPHOGENESIS USING COMPUTER MODELING \\ Results}

1.1. Determining the mechanical characteristics of materials for dome buildings

In the Arctic and Northern territories, matters of the fast erection of buildings, optimization of logistics flows and use of high-strength materials that can withstand ambient temperatures below zero for a long time are important. In the authors' opinion, such materials include those based on wood and plastic.

An empirical study was conducted with experimental testing of samples of heat-resistant polyamide 6 (caprolon, PA6) (standard / fiber-filled / extruded) used in the specified temperature ranges from +200 to -60 degrees.

In the course of the experiment, we studied the properties of the materials under short-term tension loads at normal temperatures of $18-22^{\circ} \mathrm{C}$. The preparation for the experiment was conducted directly in the mechanical laboratory of the Saint Petersburg State University of Architecture and Civil Engineering. We measured the width and thickness of the sample test section in three points: at the edges and in the middle.

The experiment was conducted in accordance with the requirements using a 10 -ton universal electromechanical Instron 5982 machine (Fig. 5b) with the maximum tensile load of $100 \mathrm{kN}$. We marked the grip areas at the opposite sides of the transversal axis of symmetry, recorded the minimum cross-section area of the samples, as well as the batch numbers and the serial numbers of the samples in the batch (Table 1).

Table 1. Samples

\begin{tabular}{|c|c|}
\hline Sample No. & Description \\
\hline 1 & Standard \\
\hline 2 & Fiber-filled \\
\hline 3 & Extruded \\
\hline
\end{tabular}

a

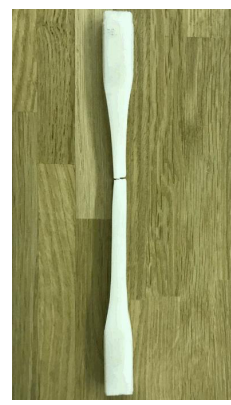

$\mathrm{b}$

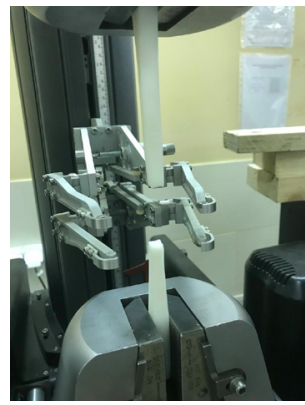

b

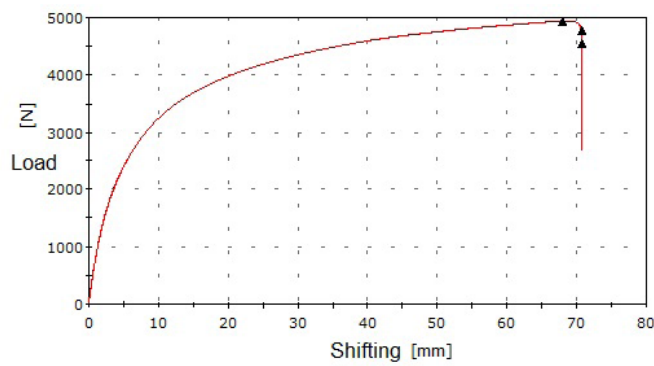

Sample №

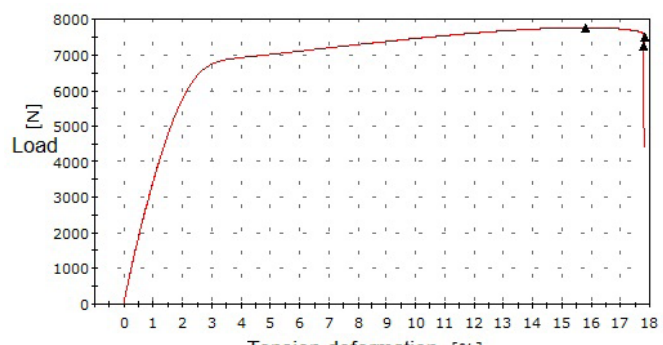

Fig. 6. Tension deformation vs. load diagram: a - standard; b - fiber-filled

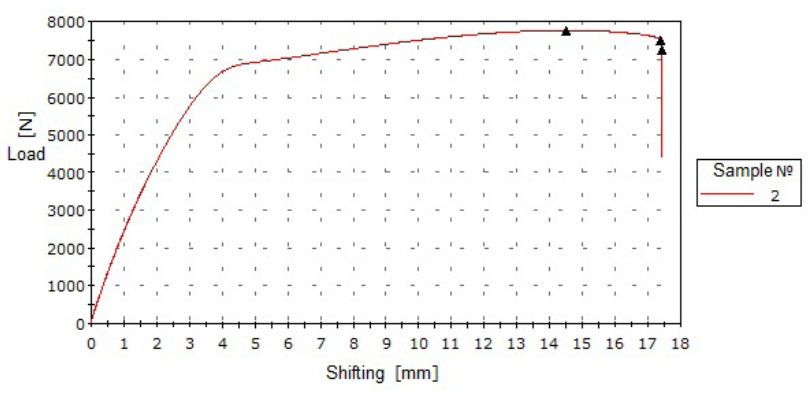

c

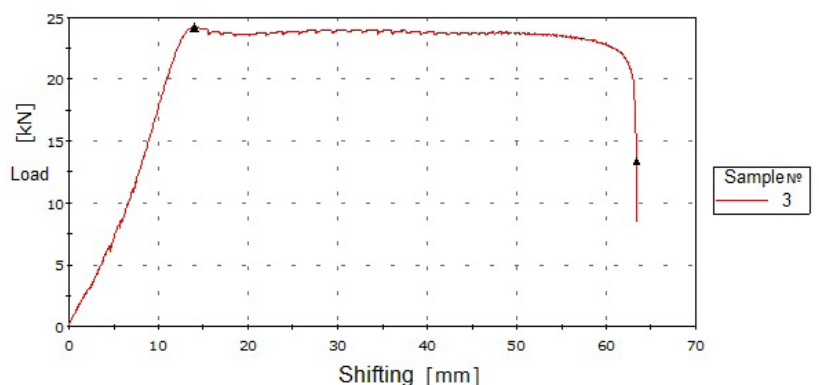

Fig. 7. Shifting vs. load diagram:

a — standard normal PA6; b - fiber-filled PA6; c - extruded PA6 
The test results are given in Table 2

Table 2. Test results

\begin{tabular}{|c|c|c|c|c|c|c|}
\hline No. & $\begin{array}{c}\text { Load } \\
{[\mathrm{kN}]}\end{array}$ & $\begin{array}{c}\text { Breaking stress } \\
{[\mathrm{MPa}]}\end{array}$ & $\begin{array}{c}\text { Modulus } \\
{[\mathrm{MPa}]}\end{array}$ & $\begin{array}{c}\text { Breaking } \\
\text { elongation } \\
{[\%]}\end{array}$ & $\begin{array}{c}\text { Samplection, a*b, } \\
\mathbf{m m} 2\end{array}$ \\
\hline 1 & 4.94 & 49.38 & 267.99 & 67.07 & Standard PA6 & $10 \times 10=100$ \\
\hline 2 & 7.76 & 77.62 & 2484.15 & 17.79 & Fiber-filled PA6 & $10 \times 10=100$ \\
\hline 3 & 24.20 & 68.04 & 68.56 & 105.55 & Extruded PA6 \\
\hline
\end{tabular}

The test results and the nature of breakage are related, which indicates the reliability of the data. The diagrams and figures show changes occurring in the samples, characteristic of brittle materials under a load. All the samples were destroyed gradually, the deformation values gradually increased under a load, transitioning from plastic flow to brittle fracture.

\subsection{Tensile testing of a joint connection for dome} structures

The sample was manufactured in accordance with the regulations, by means of milling a solid material of joint elements.

The following materials were used for the nodal joint:

- pinewood of normal moisture for the rods;

- fiber-filled polyamide PA6 for the housing, covers; diameter $-12 \mathrm{~mm}$, in the form of threaded pins, nuts and washers for the assembly of the edge joint;

- steel plates, width - 8 and $10 \mathrm{~mm}$, for lifting gear and center adjustment of the transferred tensile stresses;

- steel bolts, nuts and washers, diameter - $10 \mathrm{~mm}$, for the assembly of the fittings node.

The preparation for the experiment was conducted directly in the mechanical laboratory of the Saint Petersburg State University of Architecture and Civil Engineering at normal temperatures of $18-22^{\circ} \mathrm{C}$. The sample was assembled before the experiment (Fig. 8a).
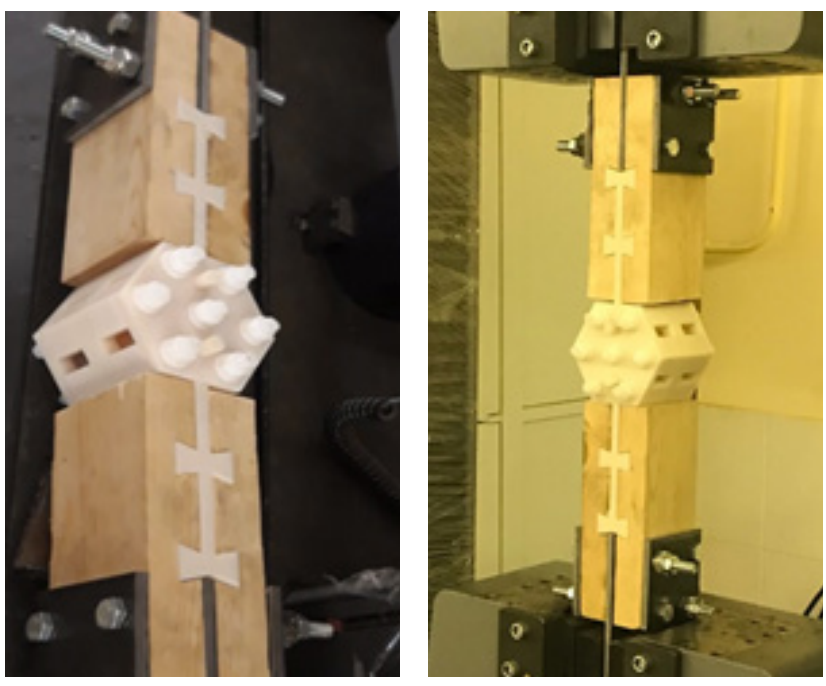

a

b

Fig. 8: $a-$ the assembly; $b$ - the tested node in the Instron 5998 tensile machine. Photo by D. Zhivotov
The experiment was conducted in accordance with the requirements using a 20 -ton universal electromechanical Instron 5998 machine (Fig. 8b) with the maximum tensile load of $200 \mathrm{kN}$.

In the course of the experiment, we analyzed the mechanical characteristics of the node made of wood and plastic material. We studied the behavior of the material under a load, phase deformations and the shifting vs. load relationship.

Fig. 9 shows the test data as a shifting vs. load curve. One sample was tested. Its photos are given in Fig. 10.

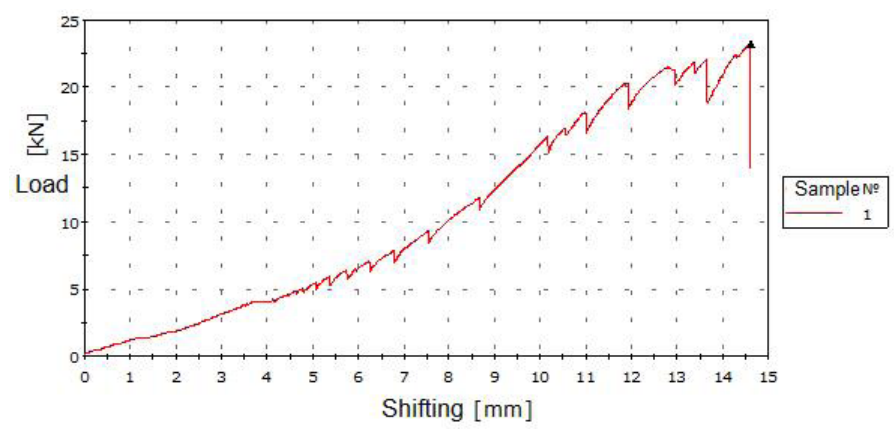

Fig. 9. Shifting vs. load diagram
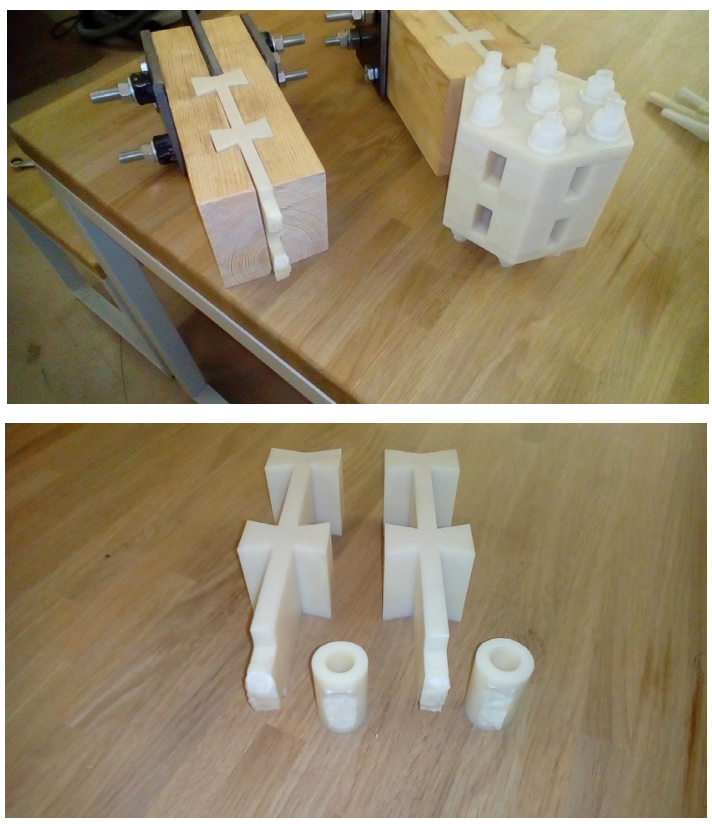

Fig. 10: $a$ - the destroyed node, $b-$ the destroyed elements of the node. Photo by D. Zhivotov 
The fiber-filled node was destroyed gradually. The deformation values gradually increased under the load, transitioning from plastic flow to brittle fracture. A comparison of the test results with calculations confirms that they are identical.

The destruction occurred in pulling out the blade from the node housing when the load reached $70 \%$ of the expected value of $23.22 \mathrm{kN}$ due to the insufficient cross-section.

\section{Discussion}

1. Various physical and mechanical properties of plastic intended by manufacturers require additional studies and analysis to be used as a load-bearing structural member, in order to find an optimal solution ensuring a balance between the and the necessary properties.
2. The results of determining the tensile strength of the material in normal conditions were obtained at temperatures of $-20,-40$ and $-60^{\circ} \mathrm{C}$ for extruded polyamide and block polycarbonate.

3. The destruction occurred when the blades broke off the node body due to the stress concentration in this point. The authors decided to continue the construction of the joint by increasing the cross-section area and flattening corners.

4. The experimental studied showed that the suggested design is quite viable. In the course of the experiment, the behavior of individual elements and the node as a whole was studied. Additional studies are required to test the node with destruction in the node body along the minimum cross-section. 


\section{References}

Bushin, V. I., Zhivotov, D.A. and Podolsky, D. M. (2017). Assembly of bearing rods for geodesic dome and other spatial structures. Patent No. RU170483U.

DOMZELT Deutschland (2020). Domes. [online] Available at: https://www.domzelt.de [Date accessed 19.02.2020].

Forumhouse (2020). A greenhouse for living: warm and nutritious all year round. [online] Available at: https://www.forumhouse. ru/articles/other/4885 [Date accessed 19.02.2020].

Fullerdome (2020). Dome house in Yakutsk. [online] Available at: https://fullerdome.com/dom-pod-kupolom-v-yakutske [Date accessed 19.02.2020].

Geodesic Earthworks (2020). Geodesic Earthworks ${ }^{\mathrm{TM}}$ earth sheltered buildings. [online] Available at: https://www. geodesicearthworks.com [Date accessed 19.02.2020].

Guan, Y., Virgin, L. N. and Helm, D. (2018). Structural behavior of shallow geodesic lattice domes. International Journal of Solids and Structures, 155, pp. 225-239. DOI: 10.1016/j.ijsolstr.2018.07.022.

Icedom (2020). Dome construction projects. [online] Available at: https://www.icedom.ru [Date accessed 19.02.2020].

Ignatyeva, K. (2019). [online] Available at: https://m.facebook.com/kyydaana.ignateva [Date accessed 19.02.2020].

Livelnternet (2020). R. Bucky Fuller. [online] Available at: http://eldisblog.com/post198737504/ [Date accessed 19.02.2020].

Ongreenway (2020). Fuller's geosphere (geodesic dome) - an impressive solution in green construction for the purposes of tourism, outreach and organic farming. [online] Available at: https://ongreenway.org/2014/12/geosfera-fullera-geodezicheskijkupo/ [Date accessed 19.02.2020].

Porta-Gándara, M. A. and Gómez-Muñoz, V. (2005). Solar performance of an electrochromic geodesic dome roof. Energy, 30 (13), pp. 2474-2486. DOI: 10.1016/j.energy.2004.12.001.

Rizzuto, J. P. (2018). Experimental investigation of reciprocally supported element (RSE) lattice honeycomb domes structural behavior. Engineering Structures, 166, pp. 496-510. DOI: 10.1016/j.engstruct.2018.03.094.

Tomsky, A. (2019). The first experimental dome in Yakutsk. [online] Available at: https://m.facebook.com/arsentomsky/ posts/3256448241092818 [Date accessed 19.022020].

Wu, Y. and Takatsuka, M. (2006). Spherical self-organizing map using efficient indexed geodesic data structure. Neural Networks, 19 (6-7), pp. 900-910. DOI: 10.1016/j.neunet.2006.05.021.

Zhivotov, D. A. and Latuta, V.V. (2019). Improvement of techniques for the construction of spatial structures in the form of geodesic domes. Proceedings of the 75th Scientific Conference of Professors, Lecturers, Researchers, Engineers and Postgraduate Students of the Saint Petersburg State University of Architecture and Civil Engineering. Saint Petersburg: Saint Petersburg State University of Architecture and Civil Engineering, pp. 231-237. 


\title{
ПРИМЕНЕНИЕ ПРОСТРАНСТВЕННЫХ ГЕОДЕЗИЧЕСКИХ КУПОЛОВ ИЗ ДЕРЕВА И ТЕРМОПЛАСТОВ ДЛЯ ВАХТОВЫХ ПОСЕЛКОВ В АРКТИКЕ И СЕВЕРНЫХ ТЕРРИТОРИЯХ
}

\author{
Дмитрий Андреевич Животов*, Валерий Валерьевич Латута \\ Санкт-Петербургский государственный архитектурно-строительный университет \\ 2-я Красноармейская ул., 4, Санкт-Петербург, Россия \\ *E-mail: d.zhivotov@mail.ru
}

\begin{abstract}
Аннотация
Использование современных строительных материалов и технологий позволяет взглянуть на, казалось бы, привычные архитектору и инженеру большепролетные пространственные сооружения в виде геодезических куполов, с другой стороны. Методы: Авторы статьи, основываясь на исследованиях отечественных и зарубежных ученых, предлагают использовать пространство между двумя геодезическими куполами для размещения жилых, административных и лабораторных исследовательских объектов. Результаты: Предлагается рассмотреть возможность использования этих типов конструкций из дерева и термопластов для вахтовых поселков на арктических и северных территориях. Обсуждение: Проводятся экспериментальные исследования для обоснования возможности изготовления узловых соединений из различных видов пластмасс.
\end{abstract}

\section{Ключевые слова}

Жилищное строительство, архитектура, строительство, испытание замороженного образца. 